\title{
INTEGRATION OF INFORMATION AND COMMMUNICATION TECHNOLOGY (ICT) IN INSTRUCTIONAL DELIVERY AMONG LECTURERS OF PART-TIME POSTGRADUATE PROGRAMMES IN THE DEPARTMENT OF LIBRARY AND INFORMATION SCIENCE, AHMADU BELLO UNIVERSITY, ZARIA
}

\author{
BOOR, C. H. M.; Prof. A. K. TUKUR AND A. A. YUNUSA
}

\begin{abstract}
The advancement which ICT resources offer in university education can be evidenced through instructional delivery. Productive instructional delivery enhances learner's creativity and intellectual development through the use of ICT resources. The level of utilization of ICTin the field of information management education is still low; recent studies have shown that many lecturers hardly comprehend the benefit of ICT in the teaching of information professionals. This study examined the state of ICT integration in instructional delivery of part-time postgraduate program in Department of Library and Information Science, ABU-Zaria.Five research questions were formulated to guide the study while, Survey research design was adopted, Structured questionnaire was used to obtain data from nine lecturers selected from the department of library and information science, using Random sampling technique.The study found that ICT when used for Instructional delivery brings about high standard of communication between lecturers and students in understanding themselves, saving time during instructional delivery and leads to quick and faster understanding of the topics taught. It is recommended that lecturers should always deploy and use ICT in instructional delivery as it enhances recall and retention of what has been taught and facilitates the development and training of information professional skills towards greater human resource development.
\end{abstract}

Keywords: Information and Communication Technology (ICT), Instructional delivery, part-time postgraduate programmes, information management education

\section{Introduction}

Today, technology has become a strong device for information huddling in university lecture rooms. It provides both the lecturers and their students with a wide range of tools and facilities to achieve the goals and objectives of the lecture and assist in improving their instructional delivery. Technology has shown a clear impact on the basic character of instructional delivery. Information and communication technology has grown very rapidly in the last two decades across disciplines. Asian Development Bank (2003) asserted that developing countries have great potential to compete successfully in the new global market, but unless they embrace the use of Information and Communication Technology (ICT) revolution promptly and actively, they will face new barriers and risks of not just being marginalized but completely surpassed. Sambo (2008) states that, development of ICT has brought in many changes, rapid growth and development in all human activities.

Information and Communication Technology (ICT) is an electronic based system of information transmission, reception, processing and retrieval which has drastically changed the way we think, the way we live in our immediate environment and can be used to access global knowledge and communicate with other people (Thomas and Trudi, 2012). Spodark, (2003) viewed information and communication technology (ICT) as an innovative device that carry out such functions as receiving, storing computer data, analyzing, transmitting and retrieving information presented to them and allowing for one-to-one, or group communication among humans. In similar vein, Onasanya, (2009) 
Integration of Information and Communication Technology (ICT) in Instructional Delivery Among Lecturers of Part-Time Postgraduate Programmes in the Department of Library And Information Science, Ahmadu Bello University, Zaria

states that, modern day businesses are conducted and facilitated through the use of telephones, fax machines and computer communication networks through the internet, adding that, the phenomenon has given birth to the contemporary e-commerce, egovernment, e-banking, e-book, e-medicine and e-education among others. Zubairu, (2013) summed up that, this involves the use of computers, internet and other telecommunication technology in every aspect of human endeavors.

The place of ICT in instructional delivery cannot be over emphasised, because the field of education has been positively affected by information and communication technologies which are also transforming instructional delivery and research. McConnell (2007) observed that many nations of the world have transformed their postgraduate lecturers and students by ICT production methods. These reforms if adopted can also make instructional delivery in Ahmadu Bello University (ABU) Zaria postgraduate programs much more interesting and relevant to meet not only the needs of the society, but also the outside world. Adopting modern approaches to instructional delivery will also allow postgraduate students to take advantage of economic opportunities and also become active players in their own economy and reduce the rate of unemployment in the country.UNESCO (2011) assert that "ICT resources has revolutionized the way people work, and is also transforming lecture and instructional delivery". It then follows that postgraduate students should be equipped with the skills and technologies, that will enhance their efficiency and make them effective to fit in tomorrow's world which is potentially technologically driven.

Application of Information and Communication Technology in instructional delivery has proved and improved in capturing, storing, retrieval, analysis and communicating or passing information in the lecture rooms, whether in the form of data text images or voice. The use of Information and Communication Technology (ICT) has brought about worldwide advances in communication. According to Yusuf and Abolade (2005) ICT has resulted in major changes in basic educational operations as well as managing instructions in different postgraduate lecture rooms. Adepoju (2013) reports that ICT has impact on the quality and quantity of teaching and learning such that it has the potential to accelerate, enrich and deepen skills, motivate and engage students in learning, help to relate school experiences to work practices, help to create economic reliability for workers, contributes to radical changes in schools, strengthen teaching and provide opportunities for between the school and the world. UNESCO (2011) notes that ICT is increasingly playing an important role in organizations and in society's ability to produce, access, adopt and apply information. Also, Ofudu (2007) submitted that ICT is the tools for post-industrial age and the foundations for a knowledgeable economy due to their ability to facilitate the transfer and acquisition of knowledge; stressing the importance of the use of ICT in education. ICT changes the needs of education as well as the instructional and potential processes. With ICT, messages can be communicated through e-mail, telex, mobile phones and the pervasiveness of ICT has brought about rapid technological, social, political, cultural and economic transformation, which has culminated in a network society organized around ICT (Pikan,2002).

ICT resources for instructional delivery in schools serve dual purposes in effective and efficient classroom instructions, i.e. maximizing learning achievement of the learners through improvement of communication and enhancement of instruction. The National Policy on Education (2004) was reviewed to accommodate the integration of ICT into the school system in keeping with dynamics of social change and its demand on education. Zubairu, (2013) and Orunsola (2013) described ICT as an indispensable part of education 
because its application facilitates effective, efficient and productive, pedagogical activities. For instance, e-learning is one of the most common means of using ICT to provide education to students both on or off campus by means of instructing online offered via web-based systems, ICT resources are seen as tools for upgrading the standard of education in any nation, the level of compliance in implementing the ICT resources in the instructional delivery process leaves much to be desired in Nigerian tertiary educational system.

\section{Statement of the Problem}

Regardless of the strength and rapid spread of technology around the world in recent time, cursory look at the university education in Nigeria has shown that many Information Professionals in the system still rely much on the traditional lecture method rather than embrace the use of ICT. Recent studies show that the level of appreciation and competencies of educators in information management is indeed very low; most lecturers hardly comprehend the benefit of ICT in the teaching of information Professionals. Conventional mode of teaching pervades the length and breadth of most universities in Nigeria, thus the lecture method and course materials/prints/handouts continue to dominate lecture rooms activities. This indicates that students are still lagging behind in the trends of ICT in all forms of education. Thus, they are denied the immense opportunities offered by ICT in the teaching and learning. This challenge makes it imperative to investigate the extent of ICT tools integration in instructional delivery of the part-time program of the Library andInformation Science department of Ahmadu Bello University, Zaria with the view that it is high time university lecturers replaced the traditional pedagogical practices that are prevalent in the university system in Nigeria with modern pedagogical approache that is more effective and efficient.

\section{Objectives of the Study}

The objectives of study are to:

i. Identify the types of ICT resources available and being used by part-time postgraduate lecturers.

ii. Evaluate the level of competency or skills of part-time postgraduate lecturers in the department of Library and Information Science Part-time program.

iii. Determine the frequency of ICT resource usage by lecturers in the Department of Library and Information Science for Instructional delivery in the Part-time program.

iv. Find the impact of ICT usage in enhancing effective and efficient instructional delivery in Part-Time Postgraduate program of the Department of Library and Information Science.

\section{Research Questions}

The study is guided by the following questions:

i. What types of ICT resources are available for instructional delivery in postgraduate lecture rooms of Library and Information Science Department?

ii. What level of competence or skills do lecturers of part-time postgraduates of the Department of LIS, possess in the use of ICT for Instructional delivery?

iii. How frequently do lecturers of part-time postgraduate program of Library and Information Science use ICT for instructional delivery? 
Integration of Information and Communication Technology (ICT) in Instructional Delivery Among Lecturers of Part-Time Postgraduate Programmes in the Department of Library And Information Science,

Ahmadu Bello University, Zaria

iv. What is the impact of ICT in enhancing effective and efficient instructional delivery in Part-Time Postgraduate programmes of the department of LIS?

\section{Literature Review}

Information and communication Technology is a global phenomenon that brings people together and bring to decision makers unprecedented new tools for development. Nwachukwu, (2008) assess that, there is a real danger that the world's poor will be excluded from the ICT emerging knowledge-based global economy. Aniebonam, (2007) posits that, to enhance $21^{\text {st }}$ century skills in the field of university education, policy makers and practitioners should focus on seven keys conditions as stated by international society for teacher education as they allows for proper integration of technology.

i. Effective professional development for teachers in the integration of technology into instruction is necessary to support student learning.

ii. Educators direct application of technology must be aligned to local or state curriculum

iii. Technology must be incorporated into the daily learning schedule (i.e. not as a supplement or after school tutorial).

iv. Project-based learning and real-world simulations must be the main focus of ICT utilization.

v. Programs and application must provide individualized feedback to students and teachers and must have the ability to tailor lessons to individual student's needs.

vi. Effective and efficient ICT integration requires leadership, support and modeling from teachers/lecturers, administrators, communities and parents.

vii. ICT packages use must be incorporated in a collaborative environment to be most effective.

For ICT to be integrated effectively into the part-time postgraduate program of Library and Information Science; strategies should balance economic and social issues to allow combination of sectoral growth with the development of ICT in tertiary institution and the society, Nwite, (2007) links these, as the tertiary institutions are also required to teach computer science as a subject discipline, and also integrate it in school administration and instruction. She also adds that the federal government 1988 policy document, National Policy on computer education emphasized other components as; equipment requirement, teacher training and specific recommendation on different tertiary institutions. National Policy on Education revised (2004) reemphasized the need for the integration of ICT in Nigeria education system.

The Nigerian National Policy for information technology was the first attempt to introduce ICT in Nigeria education, three major objectives among several objectives emphasized the need to empower youths with ICT skills to prepare them for competitiveness in a global environment, education and training and establishment of multifaceted ICT institutions as centers of excellence on ICT. The document specifically noted the need for "Restructuring the Nigeria Education system at all levels to respond effectively to the challenges of the information age and in particular, the allocation of a special IT development fund for education at all levels. For these objectives to be achieved nine major strategies were outlined, these include making the use of ICT compulsory at all educational institutions, development of ICT curricula for all levels of education, using ICT in distance education and ICT companies investing in education. 


\section{Methodology}

All the resource persons enrolled for the postgraduate part-time program of the Library Information Science, ABU, Zaria constituted the target population of the study. Because this population is manageable, it is purposively considered as the sample for the study. This is in accordance with Research advisors (2006) principle of sample size determinants.Survey research design was adopted for this study; It has the advantage of been conveniently used for studyinglarge and small population without sacrificing efficiency, time, cost and accuracy.Aina and Ajiferuke, 2002 as cited in Umar, (2011).purposive sampling techniques was used to select a sample size of nine lecturers of part-time postgraduate program in the Department of Library and Information Science, ABU-Zaria. The instrument used for data collection was the questionnaire. The questionnaires were administered to the respondents and all the ninecopies were retrieved and analyzed using simple percentages, frequencies and correlations.

\section{Data presentation, Analysis and Findings}

This section presents the analysis and results of data collected from the field. Descriptive statistics i.e. frequency count and simple percentage was used to analyse and interprete thedata as follows:

Table I: Typology of ICT Resources Available for Lecturers in Part-Time PostGraduate Lecture Rooms.

\begin{tabular}{|c|c|c|c|c|c|c|c|c|c|c|c|c|c|c|c|c|c|c|}
\hline \multicolumn{2}{|c|}{ S/No. } & \multirow{2}{*}{ 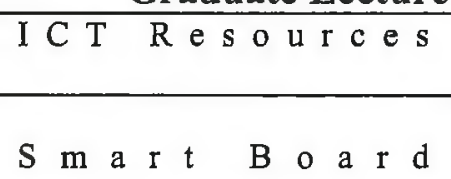 } & \multicolumn{4}{|c|}{ Readily Available } & \multicolumn{4}{|c|}{ Available (\%) } & \multicolumn{4}{|c|}{ Not Available (\%) } & \multicolumn{4}{|c|}{ Not Readily Available (\%) } \\
\hline 1 & & & 8 & 3 & . & 9 & 1 & 7 & . & 1 & 0 & & & & 0 & & & \\
\hline 2 & & Learning mange system & 0 & & & & 0 & & & & 2 & & & 7 & 9 & 7 & & 3 \\
\hline 3 & & Digita 1 Ca mera & 9 & 6 & . & 9 & 2 & 3 & . & 1 & 0 & & & & 0 & & & \\
\hline 4 & & Discplayer\& CD-ROM & 5 & 8 & . & 6 & 3 & 1 & . & 4 & 2 & & & 1 & 8 & & & 5 \\
\hline 5 & & Television set & 0 & & & & 0 & & & & 5 & 7 & & 3 & 4 & 2 & & 7 \\
\hline 6 & & $\begin{array}{lllll}R & \text { a } & \text { d } & \text { i } & 0\end{array}$ & 8 & & & 7 & 0 & & & & 4 & 2 & & 4 & 5 & 1 & . & 1 \\
\hline 7 & & Internet Connectivity & 9 & 3 & . & 4 & 6 & & & 6 & 0 & & & & 0 & & & \\
\hline 8 & & Storage \& Retrieval of MM Material & 0 & & & & 0 & & & & 6 & 4 & . & 7 & 3 & 6 & . & 2 \\
\hline 9 & & $\mathrm{C} \quad \mathrm{o} m \mathrm{~m} \quad \mathrm{u}$ t $\mathrm{e} \quad \mathrm{r} \quad \mathrm{s}$ & 7 & 9 & . & 7 & 2 & 0 & . & 3 & 0 & & & & 0 & & & \\
\hline $\begin{array}{l}1 \\
1\end{array}$ & $\begin{array}{l}0 \\
1\end{array}$ & 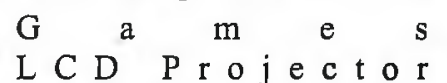 & $\begin{array}{l}5 \\
8\end{array}$ & 8 & . & $\begin{array}{l}7 \\
8\end{array}$ & $\begin{array}{l}9 \\
1\end{array}$ & 1. & . & $\begin{array}{l}7 \\
2\end{array}$ & $\begin{array}{l}3 \\
0\end{array}$ & 7 & . & 9 & $\begin{array}{l}4 \\
0\end{array}$ & 6 & . & 7 \\
\hline 1 & 2 & F a x Documents & 0 & & & & 3 & & & 4 & 2 & 4 & . & 1 & 7 & 5 & & 4 \\
\hline 1 & 3 & Video Conferencing & 0 & & & & 0 & & & & 2 & 2 & . & 7 & 7 & 7 & & 3 \\
\hline 1 & 4 & Scanning Documents & 6 & 8 & & 3 & & 1 & . & 7 & & & & & 0 & & & \\
\hline 1 & 5 & $P \circ w e r \quad P \circ i n t$ & 8 & 9 & & 9 & 1 & 0 &. & 1 & 0 & & & & 0 & & & \\
\hline 1 & 6 & $\begin{array}{llllllll}P & r & i & n & t & e & r & s\end{array}$ & 9 & 7 & . & 3 & 8 & & & 7 & 0 & & & & 0 & & & \\
\hline 1 & 7 & Electronics notice board & 0 & & & & 0 & & & & 4 & 9 & 1 & 4 & 5 & 0 & 8 & 6 \\
\hline 1 & 8 & Mob il e Phones & 6 & 3 & & 1 & 2 & 7 & . & 3 & 4 & & & 4 & 5 & & & 2 \\
\hline 1 & 9 & Bulletin Boards & 7 & 6 & . & 3 & 2 & 3 & . & 7 & 0 & & & & 0 & & & \\
\hline 2 & 0 & Spine Labeling Machine & 0 & & & & 0 & & & & 6 & 6 & & 4 & 3 & 3 & & 6 \\
\hline
\end{tabular}

The responses in Table 1; shows that, printer (97.31\%), internet connectivity (93.4\%), Power-point (89.9\%), LCD projector $(88.8 \%)$, Smart board $(83.9 \%)$, Computers $(79.7 \%)$, Video conferencing (77.3\%), Digital camera (76.9\%), Bulletin boards $(76.3 \%)$, Scanning documents $(68.3 \%)$, and Mobile phones $(63.1 \%)$ are readily available for lectures of parttime post-graduate programs in the Department of Library and Information Science, 
Integration of Information and Communication Technology (ICT) in Instructional Delivery Among Lecturers of Part-Time Postgraduate Programmes in the Department of Library And Information Science, Ahmadu Bello University, Zaria

Ahmadu Bello University-Zaria. The table shows that, the Department of LIS also possesses other ICT resources like Disc, CD-ROMs etc.

Table II: Frequency of use of ICT Resources in Part-TimePost-Graduate Lecture Rooms:

\begin{tabular}{|c|c|c|c|c|c|c|c|c|}
\hline \multicolumn{2}{|c|}{$\mathrm{S} / \mathrm{N}$} & ICT Resources & Never used & Oecasionally used & Frequently used & Most frequenty uied & Means & Std. Dev. \\
\hline 1 & . & Video Conferencing & $31(67.0)$ & $15(32.6)$ & 0 & 0 & 2.15 & 1.57 \\
\hline 2 & & Phones & $1(2.2)$ & $5(10.9)$ & $10(21.7)$ & $30(65.2)$ & 3.50 & 888 \\
\hline 3 & & $\mathrm{C} D-\mathrm{D} O \mathrm{M} \mathrm{s}$ & $13(28.3)$ & $22(62.4)$ & $7(7.3)$ & $4(8.7)$ & 2.35 & 782 \\
\hline 4 & & Internet Connectivity & $7(17.4)$ & $8(17.6)$ & $11(21.5)$ & $20(43)$. & 2.91 & 1.085 \\
\hline 5 & & Bulletin Boards & $5(10.9)$ & $12(26.1)$ & $16(34.8)$ & $13(28.3)$ & 2.80 & .981 \\
\hline 6 & & $\mathrm{D}$ i s c P l a y e r & $13(28.3)$ & $22(62.4)$ & $7(7.3)$ & $4(8.7)$ & 2.35 & .782 \\
\hline 7 & & $\mathrm{~S} m$ a $r \mathrm{t} \quad \mathrm{B}$ a $\mathrm{rd}$ & $16(34.8)$ & $15(32.2)$ & $8(17.4)$ & $7(15.2)$ & 2.13 & 1.067 \\
\hline 8 & & Lecture Notes & 0 & $2(4.3)$ & $8(17.4)$ & $36(78.3)$ & 3.74 & .535 \\
\hline 9 & & $P$ ow e $r \quad P$ o in $t$ & $\left(\begin{array}{ll}1 & 3\end{array}\right)$ & $18(39.1)$ & $12(26.1)$ & $10(28.3)$ & 2.57 & .980 \\
\hline 1 & 0 & $\mathrm{H}$ a $\mathrm{n} \mathrm{d} \mathrm{b} \mathrm{o} \mathrm{o} \mathrm{k} \mathrm{s}$ & 0 & $3(6.5)$ & $12(26.1)$ & $31(67.4)$ & & \\
\hline 1 & 1 & Online Database & $18(39.1)$ & $6(16.2)$ & $7(15.2)$ & $15(31.5)$ & 2.39 & .1 .151 \\
\hline 1 & 2 & $C \quad o \quad m \quad p \quad u \quad t \quad e r$ & $12(26.1)$ & $17(37)$ & $6\left(\begin{array}{ll}1 & 3\end{array}\right)$ & $11(23.9)$ & 2.35 & .977 \\
\hline 1 & 3 & $A$ ud io $-V$ is u a 1 & $13(23.3)$ & $8(17.8)$ & $21(45.7)$ & $4(8.7)$ & 2.35 & .782 \\
\hline 1 & 4 & $\mathrm{Ch}$ a $1 \mathrm{k} \quad \mathrm{B}$ o a $\mathrm{rd}$ & 1 & $5(6.1)$ & $12(26.1)$ & $31(67.4)$ & 3.61 & .994 \\
\hline 1 & 5 & $T \quad e x t \quad b \quad o \quad o r k s$ & $1(2.2)$ & $5(10.9)$ & $10(21.7)$ & $30(65.2)$ & 3.50 & .836 \\
\hline 1 & 6 & 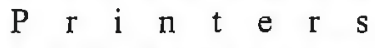 & $4(8.7)$ & $9(19.6)$ & $15(32.6)$ & $18(39.1)$ & 2.61 & .705 \\
\hline 1 & 7 & LCD Projector & $6(13)$ & $18(39.1)$ & $10(31.5)$ & $12(28.4)$ & 2.57 & .982 \\
\hline 1 & 8 & $\mathrm{~T}$ e 1 e $\mathrm{v}$ i s i o & $38(84.8)$ & $8(16.4)$ & 0 & 0 & 1.76 & .614 \\
\hline 1 & 9 & Leaning Manage System & $25(56.4)$ & $29(33.5)$ & 0 & 0 & 2.28 & .619 \\
\hline 2 & 0 & Spine Labeling Machine & $34(73.9)$ & $12(26.1)$ & 0 & 0 & 2.20 & .807 \\
\hline 2 & 1 & Scanning Document & $34(39.9)$ & $10(21.7)$ & 0 & 0 & 2.48 & 1.120 \\
\hline 2 & 2 & Electronics Notice Board & $45(94.1)$ & $11(15.1)$ & & & & \\
\hline
\end{tabular}

The response in Table II, shows the frequency of ICT usage by lecturers of part-time post-graduate programs, It shows that the most frequently used ICT resources are lecture notes, textbooks, chalkboard, bulletin board, mobile phones, computer, internet/world wide web, printers, online database, and LCD Projector, Inference drawn from this Table is that, ofall the 22 ICT resources those frequently used by the lecturers are Audio-visual, Handbooks, printers, and power-point; while electronics notice board, television, Scanning Documents, Video Conferencing and Learning manage system were least used.

Table III: Impact of ICT usage on Instructional Delivery:

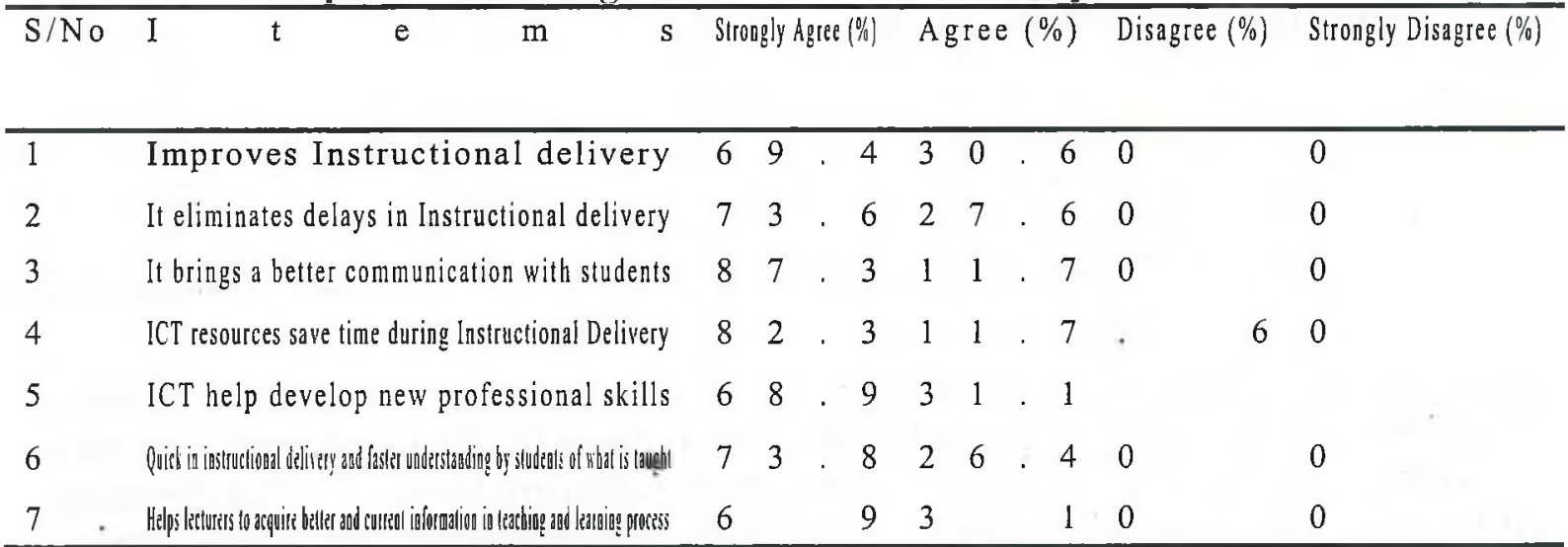


The responses in table III above; show that, using ICT during Instructional Delivery in part-time post-graduate lecture rooms could have great impacts on the whole teaching and learning process. The study found that using ICT forInstructional Delivery is believed to bring about high standard of communication between lecturers and their students in understanding themselves, saves time during Instructional Delivery, leads to quick and faster understanding among students, eliminates delays during instructional delivery, improves the quality of instructional deliver, leads to higher quality and development of teaching professional skills and helps the information professional lecturers in obtaining current and up-date information and resources for efficient instructional delivery.

Table IV: Levels of Competence and Skills of Part- Time Post-Graduate Programme Lectures in the Department of LIS

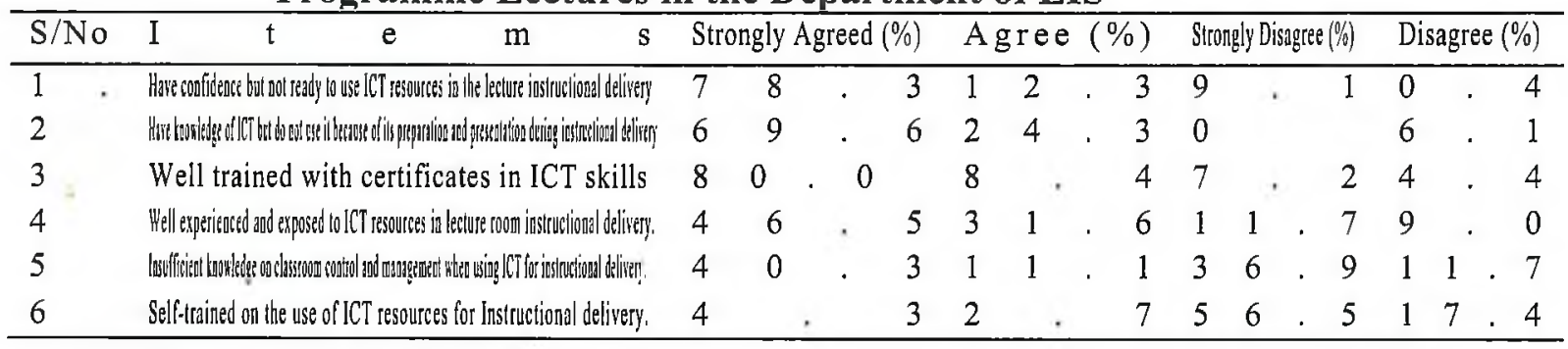

Respondents were also requested to rate their competence and skills in the use of ICT resources in the instructional delivery on a four (4) point scale; strongly Agree (SA) $=1$, Agree $=2$, Strongly Disagree $=3$, and Disagree $=4$, The results presented in Table IV, show that, most Lecturers of post-graduate programmeshave ICT skills, have confidence in the use of ICT but are not ready to use ICT for instructional delivery. It also shows that they are knowledgeable about ICT but are not ready to use it because it is cumbersome when preparing and presenting during classroom instructional delivery.

\section{Summary of Findings}

The summary of the research findings is as follows:

1. Information and communication technology (ICT) resources needed for instructional delivery in the part-time post-graduate lecture rooms of library and information science are readily available at $68.3 \%$ to $97.31 \%$ as revealed by the findings.

2. The study also revealed that, the most frequently used ICT resources in part-time post-graduate classrooms of library and information science are; Mobile phones, Internet connectivity, Online database, Power point, Printers, and LCD projector.

3. ICT when used for Instructional Delivery brings about high standard of communication between lecturers and their students in understanding themselves, saving their time during Instructional Delivery.

4. The research also reveals that, lecturers in part-time post-graduate programmes have the requisite capabilities, competencies and skills in the use of ICT in instructional delivery but do not use it regularly.

\section{Implications}

The implications of the findings are as follows: 
Integration of Information and Conmunication Technology (ICT) in Instructional Delivery Among Lecturers of Part-Time Postgraduate Programmes in the Department of Library And Information Science, Ahmadu Bello University, Zaria

- Part-time post-graduate programme lecturers in the department of library and information, Ahamdu Bello University Zaria agree with the need and benefits of using ICT in instructional delivery.

- The lecturers appreciatethe importance of using ICT instructional delivery as it leads student to and quick and faster understanding during classroom instructional delivery.

- The integration of ICT in part-time post-graduate classrooms of library and information science becomes an acceptable norm as they bring the most realistic way and means of providing timely, accurate and efficient information for instructional delivery (Arinze, Okonkwo, and Iwunor, 2012)

\section{Conclusion}

In order to have a pleasant classroom instructional delivery, lecturers should always apply the use of Information and Communication Technology (ICT) in their classroom teaching and learning. ICT is a process that can lead lecturers to a better communication with their students. Lecturers should always use ICT in instructional delivery as it saves lecturer's time. This is in agreement with Aiyebelehin, (2011) stress that, for information managers to meet the current information demand in the $21^{\text {st }}$ century, they must aggressively integrate the use of ICT into their lecture rooms for instructional delivery.

\section{Recommendations}

Following the study's expositions that, the integration of ICT in instructional delivery becomes necessary as it greatly improves and enhances teaching and learning, the following recommendations were made:

- $\quad$ Part-time postgraduate programme lecturers should always develop the use of ICT in their instructional delivery

- Lecturers teaching informational professionals should be well trained and knowledgeable in operating ICT resources in order to apply them during instructional delivery.

- $\quad$ Part-time lecturers should develop competencies required to apply ICT in their instructional delivery as it enhances and facilitates instructional delivery towards the development and training of information professional skills towards greater human resource development. 


\section{References}

Adeyemi, T. O. \& Olaleye, F. O. (2010). Information and Communication Technology for Effective Management for Secondary Schools for Sustainable Development in Ekiti State, Nigeria. American-Eurasian Journal of Scientific Research, 5 (2): 106-113.

Adepoju, S. A. (2013). Investigation of ICT Utilization in Instructional Delivery among Basic Technology Teachers in Junior secondary schools in Kwara State. Unpublished M.Ed. Thesis. Department of Educational Foundation and Curriculum, ABU, Zaria.

Aiyebelehin, J. A. (2011). Information and communication technology application in collection development in connect university library Ota, Nigeria.

Aniebonam M. C. (2007). Using Technology to Drive Education Reforms in Nigeria. URL: http://ww.buvusa.gov/nigeria/en/134.pdf. (retrieved November 23,2007).

Arinze, F. O.; Okonkwo, E. N. \& Iwunor, A. N. (2012). Information and communication technology (ICT) Application in secondary Schools and Student Academic $\begin{array}{llllll}\text { Performance in Social Studies. Pp. } & 226 & - & \end{array}$ http://www.ajol.infoindex.php/afrrev/article/view/83611.

Benlihan, U. \& Serap, K. (2011). Students' Opinion on Blended Learning and its Implementation in terms of their Learning Styles. Educational Information Technologies, 16: 5:23.

Ekoja, I. I. (2011). Modern ICT Tools: Online Electronic Resources Sharing Using Web 2.0. and Its Implications for Library and Information Practice in Nigeria. Samaru Journal of Information Studies, 11.

Federal Ministry of Education (2004), Ministerial Initiative in Education for the Nigerian Education System. Abuja Federal Ministry of Education.

Federal Ministry of Education (FME) (2007). Education Reform Act. Arrangement of parts (education Sector reform Bill) Abuja: Author.

Federal Government of Nigeria (2012). National Information communication technology Policy Draft.www.techloy.com/...../2012/...National-ICT....

Krumsvik, J. (2008). Situated Learning and Teachers' Digital competence. Education Information Technologies, 16: 279 - 290.

McConnel, (2007). E-learning groups and communities. Glasgow: Bill and Bain ltd.

Nwachukwu, M. A. (2008). Development of Information Technology in Nigeria. In Drew, E. P. \& Foster.www.eHow.com

Nwite, O. (2007). Utilization of Information and communication technology in Schools: Problem and Suggestions. 
Integration of Information and Communication Technology (ICT) in Instructional Delivery Among Lecturers of Part-Time Postgraduate Programmes in the Department of Library And Information Science, Ahmadu Bello University, Zaria

Ofudu, G. O. (2007). Nigeria Literary Educators and their technological Needs in a digital age. Educ. Focus, 1 (1): 22-30.www.google.com.

Omekwu, C. (2010). "Library and Information Technology Today" Issues, Imperative Inspiration." Paper Presented at the ICT Business Session of the Information Technology Section of the Nigerian Library Association during the $49^{\text {th }}$ National Conference and Annual General Meeting of the Nigerian Library Association.Awka, 2011.

Onasanya, S. A. (2009). Innovations in Teaching/Learning: Information and Communication Technology in Education. In I.O. Abimbola\& A.O. Abolade (Eds), fundamentals principles and practices of Instruction (pp. 228-241). Ilorin, Nigeria: Bamitex.

Opeke, O. R. \& Odunlade, O. R. (2011). Awareness and Utilization of Information Resources among Polytechnic Lecturers in Nigeria. Samaru Journal of Information Studies, 11.

Pikan, N. (2002). Gender review in the Information Development Project Information systems forrural Development: Demonstration Project in Cajamarca (Peru). Unpublished Study Prepared forInfoDev.

Rosenberg. M. (2000). E. Learning Strategies for Delivering Knowledge in Digtial Age Mcgraw Hill.

Research advisors, (2006). Sample size table. Retrieved July 5,2013 fromhttp://researchadvisors.com.

Sambo, J. A. (2008). Introduction to Mass communication Practice in Nigeria.Ibadan Spectrum Sholle D. (2000). What is Information? The Flow of Bits and the Control of Chaos. Available to http://web.mit.edu/comm-forum/papers/sholle.html

Scrimshaw, P. (2004). Energizing Teachers to Make Successful Use of ICT. London: Becta. (Electronic).

Spodark, E. (March, 2003). The Obstacles to technology Integration at a small Liberal Arts University. The journal online. Retrieved july10,2005, http://www.theiournal.com/magazine/valt/articleprintversion.cfm?aid4344

Thomas P. M. \& Trudie. J. (2012). Collaborative Information Library AssessmenStrategies for Evolutionary Teaching and Learning New York weal Schuman Publishers.

Umar, L. (2011). Customer Retention strategies for information services delivery in university Libraries in North western States of Nigeria; Samaru Journal of Information studies, 11 (1 \& 2).

UNSESCO (2011). Transforming Education: The Power of ICT policies. Available at htt://unesdoc..unesco.org/images/002/118/21184e.pdf. 
World Bank, (2010). Knowledge, productivity and Innovation in Nigeria. Available at http.siteresources.worldbank.org/EDUCATION/Resource/278200109907877269/knowledge-productivity-innovation-Nigeria.pdf.

Yusuf, M. O. \& Abolade, A. O. (2005). ICTs and the Nigerian Teacher Education. Africa Journal of Educational Studies. 3 (1): I-1.

Zubairu, S. A. (2013). Assessment of Federal Colleges of Education lecturers perception on Information and Communication Technology (ICT) resources in Instructional development in Nigeria. Unpublished $\mathrm{PhD}$ Thesis. Department of Educational Foundation and Curriculum, ABU, Zaria. 